Louisiana State University

LSU Digital Commons

Faculty Publications

Department of Biological Sciences

$1-1-2003$

\title{
Mobile element-based assay for human gender determination
}

\author{
Dale J. Hedges \\ Louisiana State University \\ Jerilyn A. Walker \\ Louisiana State University \\ Pauline A. Callinan \\ Louisiana State University \\ Jaiprakash G. Shewale \\ ReliaGene Technologies, Inc. \\ Sudhir K. Sinha \\ ReliaGene Technologies, Inc.
}

See next page for additional authors

Follow this and additional works at: https://digitalcommons.Isu.edu/biosci_pubs

\section{Recommended Citation}

Hedges, D., Walker, J., Callinan, P., Shewale, J., Sinha, S., \& Batzer, M. (2003). Mobile element-based assay for human gender determination. Analytical Biochemistry, 312 (1), 77-79. https://doi.org/10.1016/ S0003-2697(02)00430-X

This Article is brought to you for free and open access by the Department of Biological Sciences at LSU Digital Commons. It has been accepted for inclusion in Faculty Publications by an authorized administrator of LSU Digital Commons. For more information, please contact ir@lsu.edu. 


\section{Authors}

Dale J. Hedges, Jerilyn A. Walker, Pauline A. Callinan, Jaiprakash G. Shewale, Sudhir K. Sinha, and Mark A. Batzer 


\title{
Notes \& Tips
}

\section{Mobile element-based assay for human gender determination}

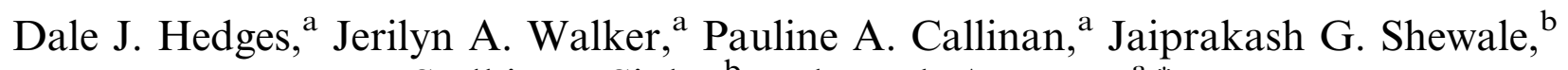 \\ Sudhir K. Sinha, ${ }^{\mathrm{b}}$ and Mark A. Batzer ${ }^{\mathrm{a}, *}$ \\ a Department of Biological Sciences, Biological Computation and Visualization Center, Louisiana State University, \\ 202 Life Sciences Building, Baton Rouge, LA 70803, USA \\ ${ }^{\mathrm{b}}$ ReliaGene Technologies, Inc., 5525 Mounes Street, Suite 101, New Orleans, LA 70123, USA
}

Received 20 August 2002

Determination of gender from human DNA samples is a common problem in forensic laboratories. While several PCR-based assays are currently available for human sex typing, each of the current approaches has limitations. Methods based on male-specific amplification, such as the amplification of the SRY locus [1], lack an internal positive control to discriminate between female DNA and male DNA which has failed to amplify for technical reasons. Restriction fragment length polymorphism assays based on sex-specific mutations at the ZFX/ZFY locus [2] require a second enzyme digestion or hybridization step following the initial PCR amplification. A recent method proposed by Cali et al. [3] based on a single adenine insertion within a tandem repeat array at the DXYS156 locus requires access to allele detection equipment potentially unavailable to forensic labs with limited resources. The most widely used approach is based on the Amelogenin locus, which yields different-sized PCR amplicons for the X and Y chromosome versions of the Amelogenin gene [4]. However, this method misidentifies males as females in some cases due to a deletion in the AMEL Y region [57]. This deletion has previously been reported to be present at a frequency of $0.018 \%$ in Caucasian males, $1.85 \%$ among Indians, and as high as $8 \%$ in Sri Lankans [5-7]. While the frequency of the deletion is relatively low, the crucial nature of forensic test results in circumstances such as rape and prenatal gender determination where there is risk for male-specific inherited disorders makes any source of error a legitimate cause for concern. This has led several researchers to recommend that Amelogenin should not be relied upon as the sole determinant of gender [5-8]. Here, we present an

\footnotetext{
${ }^{*}$ Corresponding author. Fax: 1-225-578-7113.

E-mail address: mbatzer@1su.edu (M.A. Batzer).
}

alternative PCR method of human gender identification based on the presence/absence of Alu sequences.

Alu elements are transposable elements which have amplified throughout primate evolution and comprise roughly $10 \%$ of the human genome [9]. Alu insertions are generally considered to be homoplasy free with respect to human population genetics, as the probability of two Alu elements independently inserting in the same genomic location is extremely small [9]. The insertion of an Alu element into a nonrecombining $\mathrm{X}-\mathrm{Y}$ homologous region creates a way of differentiating between inserted and noninserted chromosomes based on PCR amplicon size. While some recently integrated Alu insertions remain polymorphic in the human population, many ultimately reach fixation for the presence of the Alu insertion [9]. Fixed insertions on either the $\mathrm{X}$ or the $\mathrm{Y}$ chromosome provide a way of identifying the respective chromosome, as the inserted chromosome yields a larger fragment when the homologous region is amplified with PCR (Fig. 1). By screening X-Y homologous Alu insertions for levels of insertion polymorphism, we identified two monomorphic Alu insertions that meet the necessary criteria for a gender determination assay, one fixed on the $\mathrm{X}$ chromosome, AluSTXa, and one fixed on the Y chromosome, AluSTYa. Both of the Alu elements presumably inserted and reached fixation in the human lineage prior to the radiation of modern humans from Africa. Amplification of DNA samples from 778 diverse (African-American, EuropeanAmerican, and Hispanic-American) individuals of defined sex from paternity/identity cases for both the AluSTYa and the AluSTXa loci showed 100\% accuracy in gender identification. The DNA samples used in the study consisted of 389 females (278 African-American, 102 European-American, and 9 Hispanic-American) and 389 males (288 African-American, 90 European-American, and 11 Hispanic-American). 


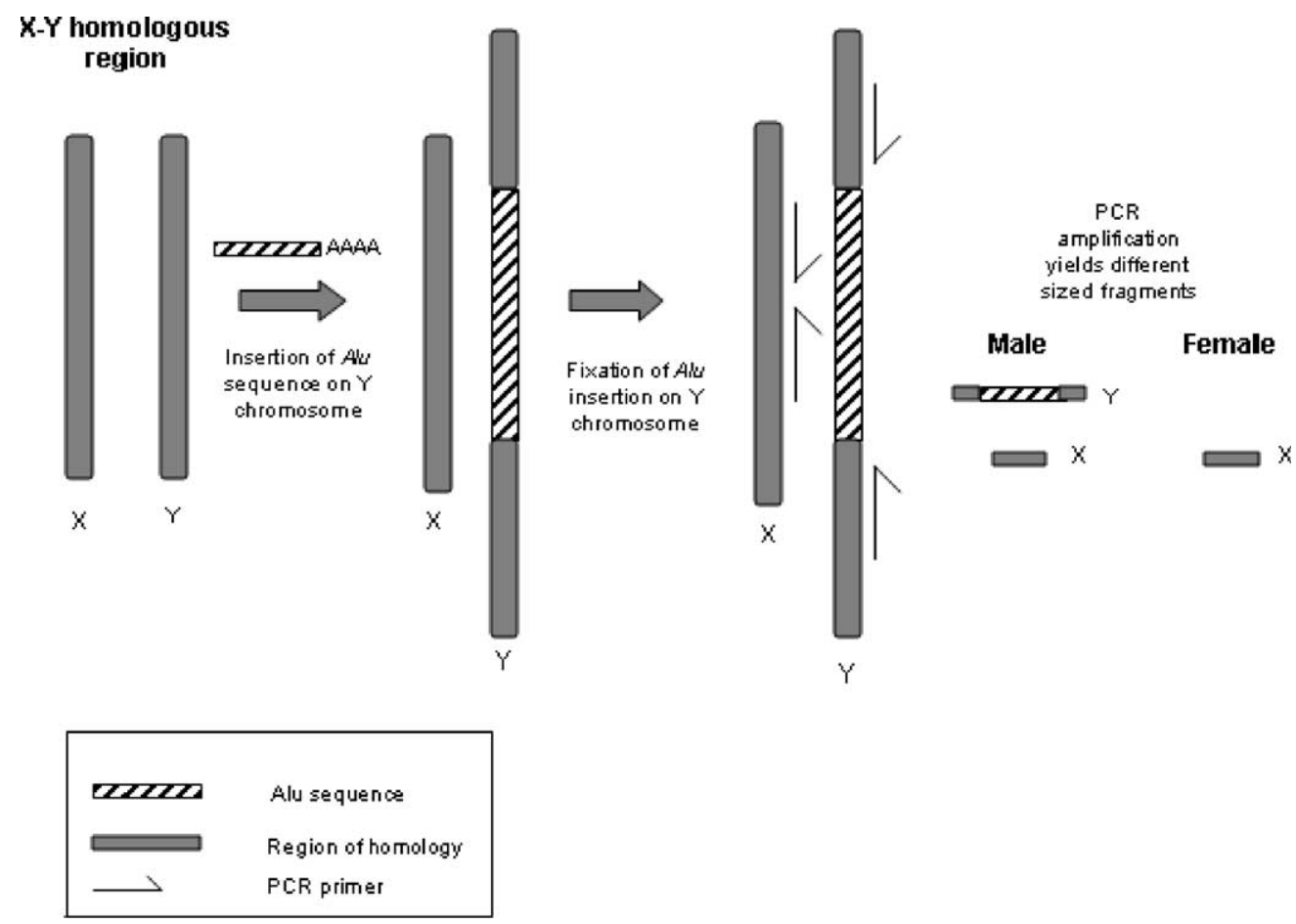

Fig. 1. Schematic diagram of mobile element-based gender determination. In the diagram an Alu insertion has occurred on the Y chromosome within an $\mathrm{X}-\mathrm{Y}$ homologous region. Once fixed in the population, the Alu insertion sequence results in a larger amplicon on the $\mathrm{Y}$ chromosome, allowing for the differentiation of the sex chromosomes via PCR amplification. X chromosome-specific insertions function in the same manner.

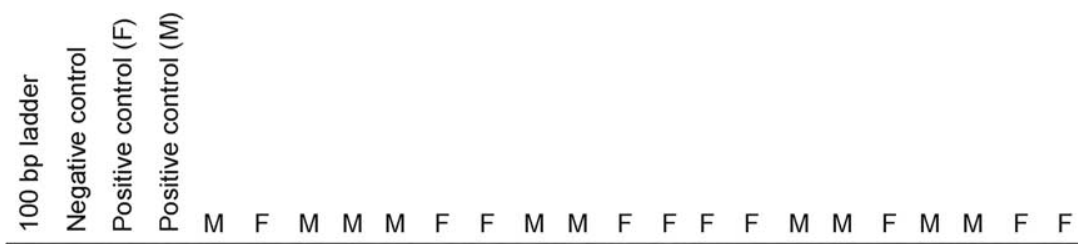

(A) AluSTXa

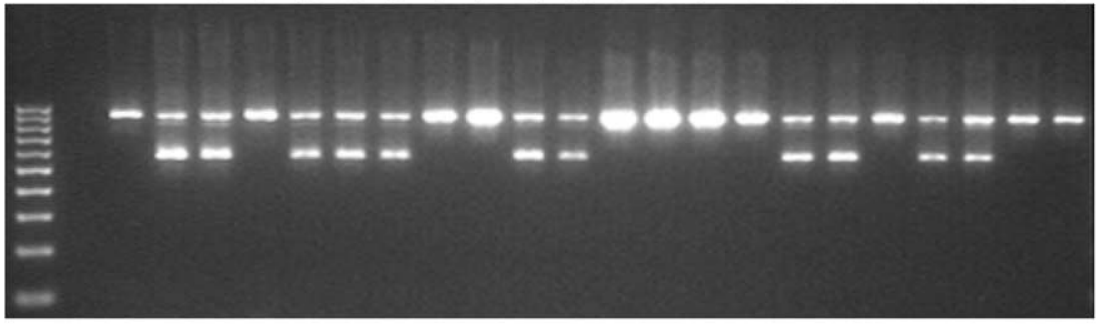

$878 \mathrm{bp}$

$556 \mathrm{bp}$

(B) AluSTYa

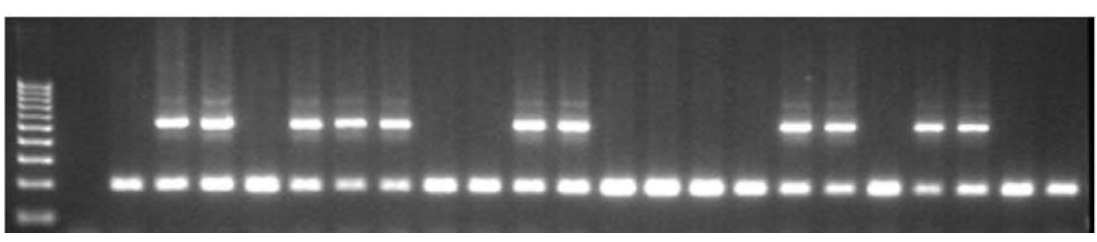

$528 \mathrm{bp}$

$199 \mathrm{bp}$

Fig. 2. Mobile element-based gender determination. An agarose gel chromatograph from the analysis of 22 individuals using the genetic systems (A) AluSTXa and (B) AluSTYa is shown. Males are distinguished by the presence of two DNA fragments, while females have a single amplicon. F (female) and M (male) above each sample indicate the known gender. Individual PCR amplifications were performed in $25-\mu l$ reactions using $25 \mathrm{ng}$ of template DNA, $0.2 \mu \mathrm{M}$ each oligonucleotide primer, $200 \mu \mathrm{M}$ deoxynucleotide-triphosphates, $1.5 \mathrm{mM} \mathrm{MgCl}_{2}, 10 \mathrm{mM}$ Tris- $\mathrm{HCl}$ ( $\mathrm{pH}$ 8.4), and Taq DNA polymerase (1 unit). Each sample was subjected to the same amplification cycle as follows: initial denaturation of $150 \mathrm{~s}$ at $94^{\circ} \mathrm{C}, 32$ cycles of $1 \mathrm{~min}$ of denaturation at $94^{\circ} \mathrm{C}, 1 \mathrm{~min}$ at the specific annealing temperature $\left(58^{\circ} \mathrm{C}\right.$ for $\mathrm{AluSTYa}$ and $60^{\circ} \mathrm{C}$ for AluSTXa), $1 \mathrm{~min}$ of extension at $72{ }^{\circ} \mathrm{C}$, followed by a final extension at $72{ }^{\circ} \mathrm{C}$ for 10 min. For analysis, $20 \mu$ of the PCR products were fractionated on a $2 \%$ agarose gel which contained $0.25 \mu \mathrm{g} / \mathrm{ml}$ of ethidium bromide. PCR products were visualized using ultraviolet fluorescence. 
Amplification of the loci was conducted via a PCR and fragments were resolved on a $2 \%$ agarose gel (Fig. 2). The primers used for the $\mathrm{Y}$ insertion, AluSTYa, were Forward 5'-CATGTATTTGATGGGGATAGAGG-3' and Reverse 5'-CCTTTTCATCCAACTACCACTGA- $3^{\prime}$, yielding an $A l u$-filled site (Y chromosome) fragment of $528 \mathrm{bp}$ and an empty site (X chromosome) fragment of $199 \mathrm{bp}$. Primers for the X insertion, AluSTXa, were Forward 5'-TGAAGAAATTCAGTTCATAGCTTGT-3' and Reverse 5'-CAGGAGATCCTGAGATTATGT GG-3', yielding an inserted (X chromosome) fragment of $878 \mathrm{bp}$ and an empty site (Y chromosome) fragment of $556 \mathrm{bp}$. For both loci, males are distinguished as having two DNA amplicons present, while females have only a single amplicon (Fig. 2).

Combining these loci together for human gender identification will provide increased accuracy for sex typing since local deletions or other types of mutations that eliminate PCR would have to occur in at least two independent genomic locations. The speed and ease of agarose-based genotyping due to the $\sim 300$-bp difference between filled and empty alleles will also enhance the utility of the assay in forensic laboratories. This approach should also be amenable to fluorescence-based amplicon detection and quantitative PCR to resolve male and female contributions to sex-mixed samples. Furthermore, similar approaches based on repetitive element insertions located in homologous sex chromosome regions should be useful for gender determination in other taxa of heterogametic sex.

\section{Acknowledgments}

This research was supported by Award No. 2001-IJCX-K004 from the Office of Justice Programs, National
Institute of Justice, Department of Justice (M.A.B.). Points of view in this document are those of the authors and do not necessarily represent the official position of the U.S. Department of Justice.

\section{References}

[1] A.H. Sinclair, P. Berta, M.S. Palmer, J.R. Hawkins, B.L. Griffiths, M.J. Smith, J.W. Foster, A.M. Frischauf, R. Lovell-Badge, P.N. Goodfellow, A gene from the human sex-determining region encodes a protein with homology to a conserved DNA-binding motif, Nature 346 (1990) 240-244.

[2] R. Reynolds, J. Varlaro, Gender determination of forensic samples using PCR amplification of ZFX/ZFY gene sequences, J. Forensic Sci. 41 (1996) 279-286.

[3] F. Cali, P. Forster, C. Kersting, M.G. Mirisola, R. D'Anna, G. De Leo, V. Romano, DXYS156: a multi-purpose short tandem repeat locus for determination of sex, paternal and maternal geographic origins and DNA fingerprinting, Int. J. Legal Med. 116 (2002) 133138.

[4] K.M. Sullivan, A. Mannucci, C.P. Kimpton, P. Gill, A rapid and quantitative DNA sex test: fluorescence-based PCR analysis of $\mathrm{X}-\mathrm{Y}$ homologous gene amelogenin, Biotechniques 15 (1993) 636-638, 631-640.

[5] F.R. Santos, A. Pandya, C. Tyler-Smith, Reliability of DNA-based sex tests, Nat. Genet. 18 (1998) 103.

[6] M. Steinlechner, B. Berger, H. Niederstatter, W. Parson, Rare failures in the amelogenin sex test, Int. J. Legal Med. 116 (2002) $117-120$

[7] K. Thangaraj, A.G. Reddy, L. Singh, Is the amelogenin gene reliable for gender identification in forensic casework and prenatal diagnosis?, Int. J. Legal Med. 116 (2002) 121-123.

[8] B. Brinkmann, Is the amelogenin sex test valid?, Int. J. Legal Med. 116 (2002) 63.

[9] M.A. Batzer, P.L. Deininger, Alu repeats and human genomic diversity, Nat. Rev. Genet. 3 (2002) 370-379. 